\title{
LETTERS
}

\section{Should Canadian medical schools have trainees funded by Saudi Arabia?}

A recent CMAJ editorial about the vulnerability of Canadian health care exposed by the withdrawal of trainees from Saudi Arabia prompted this letter. ${ }^{1}$ People exposed to these trainees speak often of the their positive qualities. However, the "bigger picture" should be noted, especially amid the tweets of Canada's Minister of Foreign Affairs, Chrystia Freeland.

Saudi Arabia is effectively a hereditary dictatorship that has deliberately targeted civilians, hospitals and schools,,$^{2,3}$ used banned munitions ${ }^{2,3}$ and conscripted children as young as eight years of age as child soldiers in Yemen, ${ }^{4}$ leading United Nations experts to describe the Saudi-led coalition's actions as possible war crimes. The Saudi-led coalition has killed over 10000 Yemenis directly from attacks and has also precipitated the death of over 150000 Yemenis from starvation, at least 50000 of whom were children. 5,6 Because of the Saudi Arabian regime's actions, Yemen is experiencing "a humanitarian catastrophe"7 and is suffering from "the world's worst humanitarian crisis."

Human Rights Watch noted, "Saudi authorities in 2018 continued to arbitrarily arrest, try, and convict peaceful dissidents. Dozens of human rights defenders and activists are serving long prison sentences for criticizing authorities or advocating political or rights reforms. Authorities systematically discriminate against women and religious minorities. In 2017, Saudi Arabia carried out 146 executions, 59 for non-violent drug crimes. A Saudi-led coalition continued an airstrike campaign against Houthi forces in Yemen that included the use of banned cluster munitions and apparently unlawful strikes that killed civilians." "It is no wonder that Ms. Freeland spoke of the human rights abuses of the Saudi regime.

One might wonder why Canadian universities accept trainees from such a repressive regime at all. Between the 1960s and 1980s, an academic boycott of South Africa (supported by the United Nations) was a critical component of a series of boycotts that ultimately led to the fall of the racist regime. Perhaps refocusing on the bigger picture will lead to the superior outcome - universities finding alternative sources of funding to the genocidal dictatorships that happen to give programs enough hush money to look away.

\section{Benjamin K.A. Thomson MD}

Associate professor, Division of

Nephrology, Department of Medicine,

Queen's University, Kingston, Ont.

Cite as: CMAJ 2018 December 17;190:

E1485. doi: 10.1503/cmaj.70797

\section{Reference}

1. Khan MH, Abdullah N, Stanbrook MB. Withdrawal of Saudi trainees exposes vulnerability of Canadian health care. CMAJ 2018;190:E1030-2.

2. Amnesty International. Yemen: the forgotten war. Available: www.amnesty.org/en/latest/news/ 2015/09/yemen-the-forgotten-war/ (accessed 2018 Oct. 12).
3. Smith R. Amnesty marks World Humanitarian Day with disturbing report into cost of air strikes in Yemen. news.com.au 2015 Aug. 19. Available: www. news.com.au/world/middle-east/amnesty-marks -world-humanitarian-day-with-disturbing-report -into-cost-of-air-strikes-in-yemen/news-story/7568f 23864573c6dedf835971ed18c44 (accessed 2018 Oct. 12).

4. United Nations Human Rights Office of the High Commissioner. Yemen: United Nations experts point to possible war crimes by parties to the conflict. Geneva: UN Human Rights Office of the High Commissioner 2018 Aug. 28. Available: www. ohchr.org/EN/NewsEvents/Pages/DisplayNews. aspx?NewsID=23479\&LangID=E (accessed 2018 Oct. 12).

5. Associated Press. 50,000 children in Yemen have died of starvation and disease so far this year, monitoring group says. Chicago Tribune 2017 Nov. 16. Available: www.chicagotribune.com/ news/nationworld/ct-save-the-children-yemen -20171116-story.html (accessed 2018 Oct. 12).

6. UN Agency chiefs call for immediate lifting of humanitarian blockade in Yemen. UN News 2017 Nov. 16. Available: https://news.un.org/ en/story/2017/11/636332-un-agency-chiefs-call -immediate-lifting-humanitarian-blockade-yemen (accessed 2018 Oct. 12).

7. United Nations Office for the Coordination of Humanitarian Affairs. Under-Secretary-General for Humanitarian Affairs and Emergency Relief Coordinator, Stephen O'Brien. Statement to the Security Council on Yemen, 31 October 2016. Available: https://reliefweb.int/sites/reliefweb.int/ files/resources/ERC_USG\%20Stephen\%200\%27 Brien\%20Security\%20Council\%20Statement $\% 20$ on $\% 20$ Yemen\%20310ct16\%20CAD.pdf (accessed 2018 Oct. 12).

8. Kouddous SA. Yemen is now the world's worst humanitarian crisis. GlobalPost 2015 Dec. 22. Available: www.pri.org/stories/2015-12-22/ yemen-now-world-s-worst-humanitarian-crisis (accessed 2018 Oct. 12).

9. Human Rights Watch. Saudi Arabia. New York: Human Rights Watch. Available: www.hrw.org/ middle-east/n-africa/saudi-arabia (accessed 2018 Nov. 21).

Competing interests: None declared. 